ІНСТИТУЦІОНАЛЬНИЙ СКЛАДНИК МЕХАНІЗМІВ РЕАЛІЗАЦІЇ ДЕРЖАВНОЇ ПОЛІТИКИ У СОЦІОГУМАНІТАРНІЙ СФЕРІ

\title{
THE INSTITUTIONAL CONSTITUENT OF NATIONAL POLICY MECHANISMS REALIZATION IN THE SOCIO-HUMANITARIAN SPHERE
}

\begin{abstract}
Досліджено теоретичні підходи до визначення сутності інституціоналізації як елементу забезпечення державної політики. Метою статmі є дослідження інституційного складника механізмів реалізації державної політики у соціогуманітарній сорері. Розкрито основні засади державної соціогуманітарної політики. Визначені напрями та сорери ії реалізації. Доведено існування декількох підходів до формування державної політики в соціогуманітарній ссрері: галузевий, просторовий, секторальний. Досліджені особливості інститучіонального забезпечення державної політики в соціогуманітарній сорері. Констатовано, що галузева структура управління соціогуманітарною сорерою існує у вигляді розрізнених вертикалей ієрархії державних органів у відповідних секторах такої політики, але вони не об'єднані сьогодні єдиним центром прийняття політичних рішень. Відзначено, що галузевий підхід у сфрері державного управління $є$ найбільш ефективним, оскільки визначає основні засади, принципи та цілі здійснення державно-управлінського впливу в однорідній сорері суспільних відносин, однорідність якої визначається єдиним контуром суспільних потреб.
\end{abstract}

Відзначено, що галузевий підхід ґрунтується на інституціональному об'єднанні, яке відповідає сучасним напрямам реалізації політики в медичній, соціальній, освітній та інших сфрерах. Зроблено висновок, що дослідження інституційного забезпечення державної політики в соціогуманітарній сорері, під інституціоналізацію державної політики в соціогуманітарній сорері пропонується розуміти формалізовану (через певну сукупність органів державної влади, інститутів громадянського суспільства, установ, організацій різних форм власності, а також органів місцевого самоврядування), структуровану та організовану у певному законодавчо визначеному порядку ієрархію рівнів розробки, запровадження та практичної реалізації державної політики, детермінованої за певними галузями та спрямованої на досягнення спільної мети розвитку соціогуманітарної ссрери. Доведено, що на теоретичному рівні $є$ такі три підходи до побудови інституціонального виміру державної політики в соціогуманітарній сфрері: галузевий, просторовий і секторальний.
Ключові слова: державна політика в соціогуманітарній сорері, інституціоналізація, галузевий підхід, гуманітарна політика, соціальна політика.

Theoretical approaches to the definition of institutionalization as an element of national policy provision are researched. The article aim is to discover the institutional constituent of national policy mechanism realization in the socio-humanitarian sphere. The main aspects of national socio-humanitarian policy are revealed. Branches and spheres of its realization are determined. The existence of a few approaches to the formation of national policy in the socio-humanitarian sphere are proved. One nominates them as specialized, spatial and sectoral ones. Peculiarities of institutional provision of national policy within the socio-humanitarian sphere are researched. It is stated that the sectoral structure of socio-humanitarian sphere administration exists in the form of distinguishing hierarchical state bodies in certain sectors of such policy but they are not united by the common center of political decisions making. It is noted that the sectoral approach in the field of national administration is the most effective one since it outlines the essential basis, principles and goals of national administration influence in the homogeneous sphere of social relations determined by the unique contour of social needs. It is emphasized that the sectoral approach is based on the institutional consolidation corresponding to modern directions of policy realization in the medical, social, educational and other spheres. It is concluded that the research of national policy institutional provision in the socio-humanitarian sphere tends to be understood as a formalized, structural and arranged in the particular legal hierarchical levels of development, implementation of national policy determined according to the certain fields focusing on achievement of common development aim of socio-humanitarian sphere. It is proved that within the theoretical level there are a few approaches to the formation of national policy institutional dimension in the socio-humanitarian sphere such as branch, special and sectoral ones.

Key words: national policy in the socio-humanitarian sphere, institutionalization, branch approach, humanitarian policy, social policy.
Постановка проблеми у загальному вигляді. Сучасний стан розвитку соціогуманітарної сфери в Україні напряму залежить від раціональності використання наявних ресурсів у державному управлінні цією сферою, а також в ефективному інституціональному забезпеченні такого управління. Держава розробляє та запроваджує соціогуманітарну політику, враховуючи потреби суспільства, але досягнення ї̈ цілей стає можливим лише у разі відповідності спроможності механізму держави проголошеним та задекларованим завданням. Для цього існує потреба у формуванні відповідної таким завданням і цілям інституційного забезпечення. Державна політика в соціогуманітарній сфері не уявляється монолітною, вона $є$ структурованою та складається з багатьох взаємозалежних елементів. Реалізація кожного елементу, запровадження кожного механізму - все це відбувається тим 
ефективніше, чим раціональніше побудовано структуру органів публічного управління в згаданій сфері. Таким чином, сьогодні постає проблема моніторингу наявного стану інституційного забезпечення державної політики в соціогуманітарній сфері та пошук потенціалу для його вдосконалення. Інституціоналізація процесів державного управління суспільними відносинами сама по собі є окремою сферою управлінської діяльності, яка вимагає створення не лише власне інституцій та інститутів, але і формування між ними зв'язків, що вимагає емпіричного виміру проблеми.

Аналіз останніх досліджень і публікацій. Саме тому останні дослідження в аналізованій сфері спрямовувалися на аналіз та оцінку сучасного стану державного управління, вирішення питань оптимізації державних ресурсів та фіксування державної політики в соціогуманітарній сфері. Однак сьогодні найбільшу актуальність отримують вже такі дослідження, як, наприклад, дослідження С.О. Москаленка в аспекті формування державної політики в соціогуманітарній сфері; Ю.І. Стельмащука - 3 питань теоретичного забезпечення державного регулювання розвитку соціально-гуманітарної сфери. Окремий інтерес викликали роботи I.В. Каріх з проблеми інституційно-правових засад політики в гуманітарній сфері, а також О.М. Петроє в контексті вдосконалення державного управління соціогуманітарним розвитком. Різні механізми державного регулювання розвитку соціогуманітарної сфери досліджувалися С.Горбатюком, В.П. Трощинським, В.А. Скуратівським, П.К. Ситнік тощо.

Виділення не вирішених раніше частин загальної проблеми. Водночас сьогодні так і не вирішено питання оптимізації інституціонального забезпечення державної політики в соціогуманітарній сфері. Є об'єктивна проблема у трансформації не лише структури органів та інститутів, але й самих підходів державної політики щодо їх формування, з'являються об'єктивні передумови для перегляду змісту механізмів управління, підвищення їх гнучкості, мобільності, що зумовлює перехід від бюрократизації державної політики до проєктного менеджменту із розширеним запровадженням механізмів та моделей ситуативного управління.

Мета статті. Метою статті є дослідження інституційного складника механізмів реалізації державної політики у соціогуманітарній сфері.

Виклад основного матеріалу. Реалізація державної політики у соціогуманітарній сфері передбачає існування досить складної системи різноспрямованих елементів держав- но-управлінського впливу на окремі сегменти соціального, культурного, релігійного буття людини. Кожен із таких вузлових елементів представляє собою сукупність суспільних відносин з отримання певних благ соціокультурного характеру. Держава створює напрями реалізації політики в означеній сфері, а також забезпечує функціонування всіх її складників винятково шляхом побудови системи органів управління, а також шляхом оптимізації ресурсного забезпечення існування таких вузлових елементів.

При цьому інституціоналізація проявляється в певному упорядкуванні органів управління соціогуманітарною сферою. Інституціоналізація державної політики у соціогуманітарній сфері є одним з основних і найбільш важливих аспектів ефективності реалізації різнихії форм. 3 погляду системного підходу організація органів влади повинна здійснюватися з огляду на певні принципи і цільові орієнтири, спрямовані, очевидно, на досягнення максимального рівня виконання завдань загальнодержавного і місцевого (локального) значення. Отже, інституціоналізація визначає архітектоніку будь-якої організаційно-управлінської системи і розглядається нами як один із способів вдосконалення системи організаційно-правового забезпечення державної політики у соціогуманітарній сфері.

Інституціоналізація є чинником зниження невизначеності й основою для прогнозування поведінки суб'єктів. Інститути пропонують схему дії в тих сферах, де ця схема не існувала, і тому в ній була невизначеність. Так, у процесі інституціоналізації відбувається заміна спонтанної поведінки на передбачувану, яка очікується і моделюється. Суспільство, створюючи інститути, закріплює певні види соціальної взаємодії, робить їх постійними та обов'язковими. Далі на цій основі розробляється система санкцій. Фіналом інституціоналізації інтересів можна вважати створення відповідно до норм і правил чіткої інституційно-рольової структури інтересів, схваленої більшістю учасників соціально-економічного процесу [6, с. 115-119].

На думку групи авторів Р. Симпсона, Дж. Тьорка [19, с. 106-108], інституціоналізація розглядається як процес формування різних видів соціальної діяльності як соціальні інститути. Завершенням процесу інституціоналізації є інтеграція нового виду соціальної діяльності в наявну структуру виробничо-економічних відносин [5, с. 55-59]. На думку авторів В. Меркеля і А. Круассана [9, с. 12], інституціоналізація - процес утворення набору правил, що задають контекст людського спі- 
віснування і взаємодії. Своєю чергою А.А. Ткач вказує, що інституціоналізація - це перетворення соціальних намірів на норму та формування правил економічного спілкування шляхом їх впровадження за допомогою владних інституцій (неписаних правил чи правової діяльності) на основі засобів правового, економічного і політичного регулювання [16, с. 126].

Натомість Н. Флігстін вважає, що інституціоналізація закріплює загальноприйняті практики, забезпечує їх збереження в незмінному вигляді протягом ряду поколінь, забезпечує перетворення абстрактних правил у реальні моделі стабільної взаємодії [17, с. 28].

Звертаючись до праць Д.Ю. Андрофагіна, можна дійти висновку, що інстітуціоналізація - це процес формування і створення соціальних, економічних і політичних інститутів як стійких форм організації діяльності господарюючих суб'єктів в економічній системі; правове та організаційне закріплення тих чи інших соціальних відносин господарюючих суб'єктів [2, с. 6]. 3 цього погляду ми можемо розглядати інституціоналізацію як процес становлення стійкого взаємозв'язку між певною сукупністю органів, що реалізують державну політику у соціогуманітарній сфері.

Л.В. Андриченко вважає, що відповідно до інституціонального підходу суб'єктами державного управління $€$ законодавчі та виконавчі органи влади, які відповідно до встановлених їм повноваженнями, здійснюють прямий і непрямий управлінський вплив на інституційну структуру суспільства [1, с. 28-30].

Своєю чергою А.Г. Давиденкова та О.О. Туфанов під інституціоналізацією розуміють явище неоднорідне і нелінійне. Тому вчені пропонують два підходи до визначення сутності інституціоналізації: «як історичний процес зародження і встановлення нових соціальних, політичних і культурних інститутів; як спосіб функціонування інститутів у рамках соціальних систем в зв'язку з процесом адаптації індивідів і колективів до їі нормативних вимог» $[4$, с. 105].

Таким чином, термін інституціоналізація визначає формування формального способу або структури соціального середовища, механізми забезпечення сталого стабільного взаємини між різними підсистемами державної політики у соціогуманітарній сфері. В.Д. Нечаєв відзначає, що «інституційна організація розуміється як специфічний для цього суспільства, внутрішньо узгоджений комплекс інститутів (формальних і неформальних правил і угод), що регулюють взаємодію індивідуальних і колективних акторів з відповідних питань» [12, с. 26-28].
П.П. Дмитрук зазначає, що результатом інституціоналізації механізму державного регулювання має бути створення умов для економічного зростання виробництва, високої конкурентоспроможності продукції, підтримки науково-технічного потенціалу, недопущення зниження рівня життя населення нижче за нормативно встановлені порогові значення, збереження соціально-економічної стабільності в суспільстві. Формування інституційної бази державного регулювання постає як результат нормотворчості ряду відповідних суб'єктів: Верховної Ради України, Президента України та безпосередньо підпорядкованих йому консультативно-дорадчих органів, органів виконавчої та судової гілок влади різних рівнів та органів місцевого самоврядування [5, с. 114-121].

Ф. Селзнік вважає, що інституціоналізація відбувається на якомусь етапі діяльності організації як наслідок накопичення традицій, а також під впливом свідомих дій керівників. Завдяки інституціоналізації організація координує діяльність персоналу, забезпечує ідентифікацію індивідів з організаційними цілями, злагоджену роботу та стабільність своїх структурних елементів [18].

Е.М. Лібанова вважає, що інституціоналізація це процес формування функціональних, нормативних та владних відносин між інституційним суб'єктом і суб'єктами його навколишнього зовнішнього середовища [8].

Узагальнюючи підходи різних течій та вчених до визначення терміну «інституціоналізація», найбільш прийнятним для подальшого аналізу можна вважати таке його трактування: інституціоналізація - це вироблення норм правил у якій-небудь галузі суспільних відносин (інститутів), тих або інших форм суспільного ладу. Таким чином, інституціоналізація нами розглядається як сукупність органів реалізації державної політики у соціогуманітарній сфері.

Враховуючи викладене вище, необхідно зауважити, що інституціоналізація державної політики у соціогуманітарній сфері визначається відповідно до законодавства України, яким регулюються різні аспекти соціогуманітарної сфери та різні її підсистеми. Саме в цьому законодавстві визначається коло державних інституцій, що наділені відповідними повноваженнями в сфері забезпечення відносин з розвитку соціогуманітарної сфери та задоволення відповідних потреб громадян належним рівнем державно-управлінського впливу. Натомість ми обстоюємо погляд, відповідно до якого до такої системи необхідно обов'язково включати органи та установи, що здійснюють реалізацію державної соціогу- 
манітарної політики на загальнодержавному, регіональному та локальному рівнях.

Але якщо провести аналіз законодавчого забезпечення державного регулювання соціогуманітарної сфери, то постають одразу дві проблеми в контексті визначення найбільш ефективної моделі інституціоналізації державної політики в означеній сфері:

- по-перше, цілком зрозуміло, що первинним структурним елементом такої моделі $€$ сукупність органів, які формують державну політику, але сукупність органів, які впроваджують таку політику, навряд чи можна визначити однозначно саме на сучасному етапі розвитку системи публічного управління в Україні;

- по-друге, важко однозначно визначити предметну сферу регулювання, оскільки вітчизняне українське законодавство не містить визначення «соціогуманітарної сфери». Через це неможливо чітко й однозначно визначити і об'єкт державно-управлінського впливу, що об'єктивно формує потребу у пошуку спочатку теоретичного, методологічного інструментарію, а вже потім практичного виразу вирішення проблеми інституціоналізації державної політики у вказаній сфері.

у цьому контексті доцільно звернутися до робіт Ю.І. Стельмащука, який зазначає, «що заходи держави стосовно регулювання соціогуманітарної сфери є неефективними через їх безсистемність і непослідовність; відсутність чітко продуманої тактики, яка базувалась би на глобальному вивченні й усебічному врахуванні наявних особливостей культурного життя, економічної, соціально-політичної, демографічної ситуації; а також через відсутність належної нормативно-правової бази, яка однозначно регулювала б управлінську діяльність у контексті загальних закономірностей національного поступу українського суспільства, захисту національних інтересів» [14]. Таким чином, ми повинні зробити висновок, що сьогодні говорити про остаточну інституціоналізацію державної політики в соціогуманітарній сфері взагалі недоцільно та передчасно. На цей час точно навіть не визначено, що саме входить та охоплюється цим поняттям. Зрозуміло, що розвиток соціально-гуманітарної сфери та формування єдиного гуманітарного простору є першочерговим завданням держави з погляду забезпечення національної єдності та самоідентичності. Але чітко визначити структуру органів державної влади, які забезпечують втілення цієї політики на практиці важко, що призводить до появи проблем другого рівня - відсутність необхідного рівня ефективності соціогуманітарної політики та неспроможність мобілізувати потенціальні ресурси на її впровадження.
Так, наприклад, В.П. Трощинський, В.А. Скуратівський, П.К. Ситніктаін та інші вказують, що органам управління охороною здоров'я всіх рівнів необхідно звернути першочергову увагу на розв'язання проблеми дотримання вимог державних соціальних стандартів надання медичної допомоги під час надання медичної допомоги пацієнтам в лікувально-профілактичних закладах. Особливу увагу слід приділити відділам охорони здоров'я районних державних адміністрацій, органам місцевого самоврядування в сільській місцевості на стан дотримання таких вимог під час надання медичних послуг у місцевих закладах охорони здоров'я [10, с. 41-42]. Це є цілком логічно для органів сфери охорони здоров'я, яка, на думку дослідників і на нашу думку, є елементом соціогуманітарної сфери. Але постає питання: яким чином інституційний складник системи охорони здоров'я включити в інституційну структуру державної політики в соціогуманітарній сфері. На думку наведених вище вчених, це має відбуватися за галузевим підходом стосовно кожного сегменту аналізованої політики держави через уніфікацію стандартів державного регулювання із одночасною ідентифікацією та деталізацією реалізації конкретних цілей та завдань держави в різних секторах соціогуманітарної сфери.

Подібного погляду дотримується також С. Горбатюк, який визначає державну гуманітарну політику як політику, яка диверсифікована за низкою напрямів: державна демографічна політика, державна політика у сфері формування та розвитку людського потенціалу (охорона здоров'я, освіта, наука й інновації, культура, фізична культура і спорт); державна політика у сфері формування ідейно-свідомісного потенціалу та національного самоусвідомлення; державна політика у сфері забезпечення конституційних прав і свобод людини і громадянина; державна політика у сфері національних відносин і релігії [4, с. 85-87]. Ми підтримуємо такий погляд через декілька причин:

- по-перше, галузева структура управління соціогуманітарної сферою існує у вигляді розрізнених вертикалей ієрархії державних органів у відповідних секторах такої політики, але вони не об'єднані сьогодні єдиним центром прийняття політичних рішень;

- по-друге, галузевий підхід у сфері державного управління є найбільш ефективним, оскільки визначає основні засади, принципи та цілі здійснення державно-управлінського впливу в однорідній сфері суспільних відносин, однорідність якої визначається єдиним контуром суспільних потреб. 
O.M. Петроє навпаки акцентує увагу на необхідності запровадження не галузевого, а просторового підходу. Так, дослідниця зазначає, що «однією з центральних проблем розвитку соціогуманітарної сфери України є недоліки наявної системи державного управління з властивою їй централізованою обтяженістю, ігноруванням регіональної специфіки, зумовленої потребами та інтересами соціогуманітарного розвитку населення різних регіонів. Тому удосконалення такої політики має здійснюватися шляхом децентралізації влади, демократизації політичних і соціально-економічних відносин, активізації процесів горизонтального (міжгалузевого, секторального) та вертикального (управлінського) співробітництва, співробітництва всіх гілок влади та місцевого самоврядування» [13, с. 72-73]. Це означає, що інституціоналізація соціогуманітарної політики повинна відбуватися шляхом відтворення стійкої єдиної ієрархії органів державної влади, яка на різних рівнях (центральному, регіональному, локальному) виступатиме центром відносин та координації діяльності інших органів та інституцій в соціогуманітарній сфері.

Цього ж погляду дотримується І.В. Каріх, яка укладає в систему соціогуманітарної політики всі сфери людського буття, які спрямовані на її розвиток як особистості та реалізацію її особистих прав, не пов'язаних із матеріальним відтворенням. «Доцільно говорити загалом про історичний, світоглядний і цивілізаційний контекст, що визначає спрямування соціогуманітарної політики та її основне ціннісне наповнення, а також виклики й загрози, пов'язані з явищами гуманітарної експансії» [6, с. 8-11]. Своєю чергою Ю.І. Стельмащук зазначає, що соціогуманітарну політику слід розділяти лише на два складники: соціальну

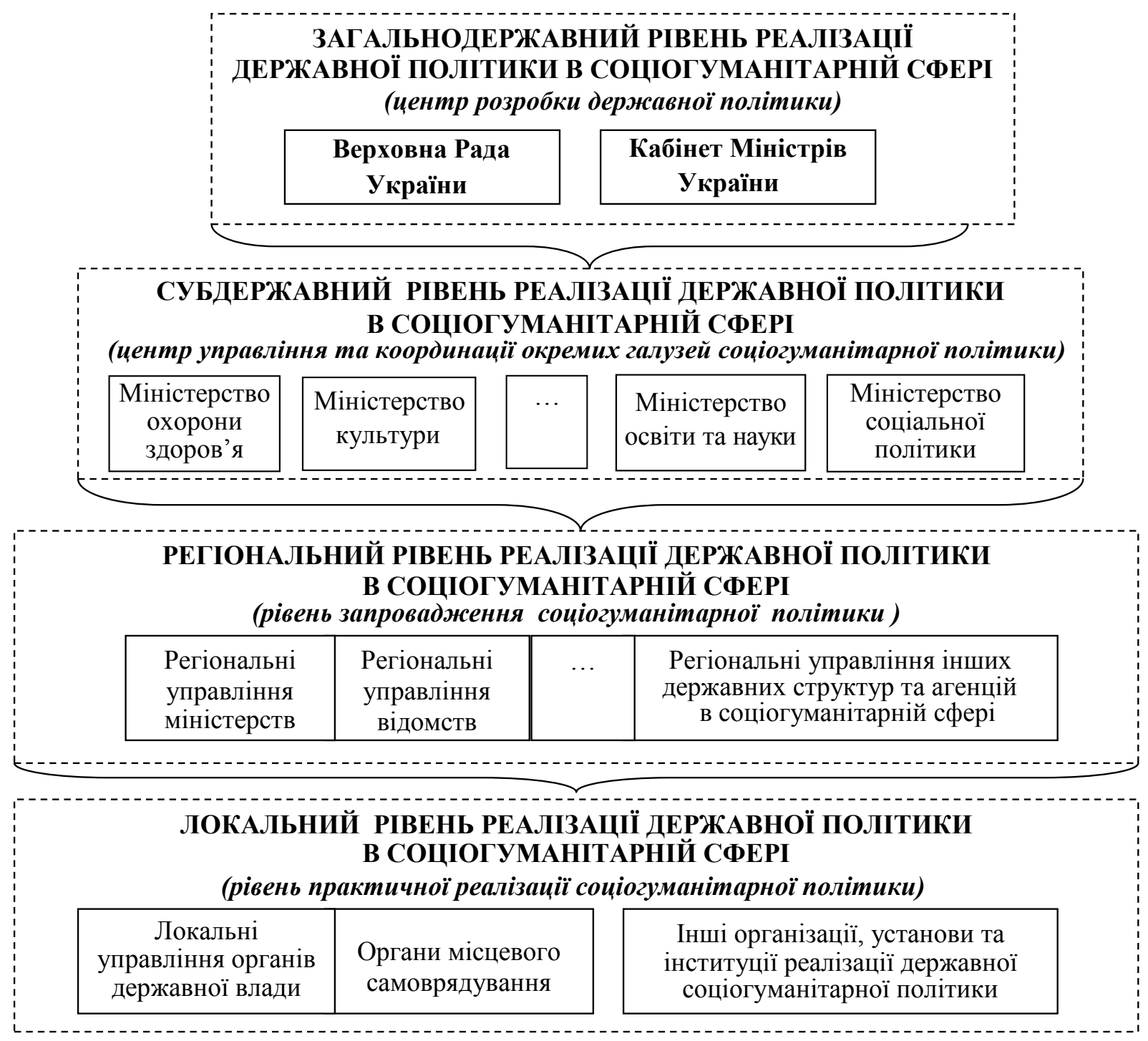

Рис. 1. Інституціональне забезпечення державної політики в соціогуманітарній сфері 
сферу (система забезпечення національних програм розвитку суспільства, яка покликана засобами та механізмами соціальної політики створювати умови для реалізації потенціалу людини, соціальної стабільності, соціального миру, високого рівня суспільної соціодинаміки) та гуманітарна сфера (включає в себе єдність об'єктивних і суб'єктивних факторів суспільного життя, що мають на меті створення умов для соціальної, інтелектуально-духовної безпеки людини і суспільства, реалізацію її соціальних, духовних потреб, формування і збагачення творчого потенціалу особи) [15, с. 94-95]. С.О. Москаленко розділяє такий підхід, але вважає при цьому, що кожна за наведених сфер має розділятися на більш дрібні сектори. Так, соціальна політика повинна детермінуватися через політику в сфері медичного та соціального забезпечення тощо, а гуманітарна - через освітню, релігійну та інші сектори суспільних відносин [11]. Таким чином, ми доходимо висновку, що сьогодні не існує певної усталеної єдності в питаннях визначення інституціоналізації державної політики в соціогуманітарній сфері навіть на теоретичному рівні.

Таким чином, ми наголошуємо на тому, що інституціональне забезпечення державної політики в соціогуманітарній сфері повинно мати такий вигляд (рис. 1).

Натомість нам уявляється цілком логічним поєднати всі наведені вище погляди. Ïх існує декілька:

- галузевий підхід - ґрунтується на інституціональному об'єднанні, яке відповідає сучасним напрямам реалізації політики в медичній, соціальній, освітній та інших сферах;

- просторовий підхід - втілюється в побудові чіткої ієрархії органів державного управління від центру прийняття політичних рішень та відповідальності за запровадження політики в соціогуманітарній сфері із подальшим формуванням відповідних виконавчих структур на рівні регіональному та локальному;

- секторальний підхід - виділення соціальної та окремо гуманітарної сфери з подальшою детермінацією на відповідні сегменти реалізації суспільних відносин щодо забезпечення особистісного розвитку та потреб людського буття.

Об'єднавши їx, ми забезпечимо необхідну централізацію, яка дасть змогу розробляти цілісну державну політику в соціогуманітарній сфері, впроваджувати її на всіх рівнях ієрархії, а також дотримуватися уніфікованих підходів та принципів під час її практичної реалізації.

Таким чином, розробляючи та визначаючи основні аспекти й засади державної політики в соціогуманітарній сфері на загальнодержавному рівні, забезпечується її цілісність. Через субдержавний рівень - рівень міністерств та відомств - відбувається деталізація основних засад і цілей державної політики у відповідні програми галузевого спрямування. Через регіональні органи та управління центральних органів державної влади в сфері соціальної, гуманітарної політики забезпечується їі практичне впровадження. А через локальний рівень - реалізація на практиці, спрямована безпосередньо на населення як основного споживача.

Висновки. Підводячи підсумки дослідження інституційного забезпечення державної політики в соціогуманітарній сфері, слід зауважити таке:

- по-перше, під інституціоналізацію державної політики в соціогуманітарній сфері пропонується розуміти формалізовану (через певну сукупність органів державної влади, інститутів громадянського суспільства, установ, організацій різних форм власності, а також органів місцевого самоврядування), структуровану та організовану у певному законодавчо визначеному порядку ієрархію рівнів розробки, запровадження та практичної реалізації державної політики, детермінованої за певними галузями та спрямованої на досягнення спільної мети розвитку соціогуманітарної сфери.

- по-друге, доведено, що на теоретичному рівні $€$ декілька підходів до побудови інституціонального виміру державної політики в соціогуманітарній сфері: галузевий підхід; просторовий підхід; секторальний підхід.

Доведено необхідність їх поєднання та побудови інституціонального забезпечення державної політики в соціогуманітарній сфері 3 єдиним центром прийняття рішень щодо розробки цілей та завдань такої політики, а також стрункою та системно виваженою ієрархією органів державної влади на різних рівнях її практичної реалізації.

\section{ЛІТЕРАТУРА:}

1. Андриченко Л.В. Проблемы правового обеспечения сохранения культурного наследия коренных малочисленных народов: международный и национальный аспекты. Журнал зарубежного законодательства и сравнительного правоведения. 2019. № 4. С. 17-32.

2. Андрофрагин Д.Ю. Механизм институционализации экономических отношений. Вестник Саратовского государственного социально-экономического университета. 2008. № 1 (20). С. 5-9.

3. Горбатюк С. Концептуалізація моделі гуманітарної політики в Україні на сучасному етапі реформ. Ефрективність державного управління. 2018. Вип. 2 (55). Ч. 1. С. 80-90. 
4. Давыденкова А.Г., Туфранов А.О. Институционализация социокультурной и экономической жизни общества: социально-фрилософские аспекты. Вестник Ленинградского государственного университета им. А.С. Пушкина. 2011. С. 96-106.

5. Дмитрук П. Інституціоналізація механізму державного регулювання економічної безпеки АР Крим: соціальний аспект. Актуальні проблеми державного управління. 2011. Вип. 4. С. 55-59.

6. Дмитрук П. Принципи інституціоналізації механізму державного регулювання економічної безпеки регіону. Державне управління та місцеве самоврядування : зб. наук. пр. 2011. Вип. 4 (11). С. 114-121.

7. Каріх І.В. Інституційно-правові засади політики національної безпеки в гуманітарній сорері : авторефр. дис.. к.політ. н. ; спеціальність 21.01.01 Київ : Національний інститут стратегічних досліджень. 2018. 22 с.

8. Лібанова Е.M. Перспективи трансорормації соціальної сфери України. Демографія та соціальна економіка. 2004. № 1-2. 54 с.

9. Меркель В., Круассан А. Формальные и несрормальные институты в дефектных демократиях. Политические исследования. 2009. № 2. С. 20.

10. Механізми державного регулювання розвитку соціогуманітарної сорери : наук. розробка [авт. кол. : В.П. Трощинський, В.А. Скуратівський, П.К. Ситніктаін]. Київ : НАДУ,2012. 52 с.

11. Москаленко С.О. Формування державної політики в соціогуманітарній сорері: комунікативна скла- дова. Державне управління: теорія та практика. 2013. № 1. URL: http://nbuv.gov.ua/UJRN/Dutp_2013_1_15.

12. Нечаев В.Д. Институциональная организация местного самоуправления в постсоветской России : автореферат дис. д. полит. н. : специальность 23.00.02. Москва, 2008. 32 с.

13. Петроє О.М. Основні напрями вдосконалення державного управління соціогуманітарним розвитком на регіональному рівні. Вісник Національної академії державного управління при Президентові України. 2014. № 2. С. 69-74.

14. Стельмащук Ю.І. Стан розвитку соціально-гуманітарної ссрери в процесі трансформаційних змін України. Державне управління: удосконалення та розвиток. 2015. №6. URL: http://www.dy.nayka.com.ua/ ?op=1\&z=1005.

15. Стельмащук Ю.І. Державне регулювання розвитку соціально-гуманітарної сорери: термінологічний інструментарій. Інвестиції: практика та досвід. 2016. № 20. C. 93-97.

16. Ткач А.А. Інституціональні основи ринкової інсрраструктури: монограсрія. Київ : НАН України, Об'єдн. ін-т економіки, 2005. 295 с.

17. Флигстин, Н. Поля, власть и социальные навыки: критический анализ новых институциональных течений. Экономическая социология. 2008. Т. 2. 55 с.

18. SelznickPh. Institutionalism"Old"and"New". Administrative Science Journal. 1996. № 2 (41). P. 270-278.

19. Turk H., Simpson R.L. Institutions and social exchange. N.Y., 1971. P. 210. 